Fried Fish as a Cause of Typhoid Fever.

In a report to the London County Couneil Mr. S. F. Murphy, the health officer, describes an outbreak of typhoid fever due to fish. Since 1899 at least four outbreaks in London have been attributed with much probability to the eating of fried fish. In the provinces two outbreaks have been ascribed to this cause. Two special features were found in the Iondon outbreaksmultiple attacks in partioular houses and an exceptional are inciden e, persons between 3 and 25 being attacked in unusual proportion. These features occurred in association with two facts-poverty and the eating of fried fish. In December, 1903 , a group of attacks occurred in the borough of Holborn, which were believed to be due to the eating of fried fish obtained in two particular shops. Every other source of infection was excluded. In several instances the subjects stated that the fish had a disagreenble odor, and even that it made them sick. The cause of contamination of the fish appears to have been imperfect removal of the entrails, which is liable to occur in cheap fish.

\section{Opticians and Spectacle Prescribing.}

A burning question in medical politics just now is the proposal of the "Company of Specta"le Makers," one of the ancient guilds of the City of London, to grant diplomas in sight testing to opticians. This proposal was severely condemned at the recent meeting of the British Merlical Association, and the Ophthalınological Society of the United Kingdom has now done likewise, and passed a resolution that "While approving of any measures which tend to increase the efficieney of opticians in their technical work it ennsiders that it would be misleading and dangerous to the public to comtenance any proposal to certify as competent to advise and prescribe for defects of vision anyone who has not had an efficient medical and surgical training. A diploma such as the Company of Spertacle Makers proposes to grant may lead the public to believe that its possessor is competent to diagnose and treat diseases of the eye. Errors of refraction often oceur in association with diseases of the eye. The mere corrertion of the former by means of spectacles would ignore a condition which might destroy sight or endanger life. Mnrenver, many errors of refraction can be accurately measured only after the use of a drug which should be used only by a medical man, since its indiscriminate use is calculated to excite one of the gravest diseases to which the eye is liable. Finally, on general grounds, it is dangerous to encourage the public in the belief that affections of any organ can be safely treated by any one unacquainted with its anatomy and physiology and with the various norbid conditions to which it is liable."

\section{Correspondence.}

\section{Club Practice in New Zealand.}

Wilangarie, New Zealand, July 7, 1904.

To the Editor:-In a recent issue of THE Journal I noticed remarks on club practice. Permit me, as one who has passed through the experience, to express myself. I am now in a country in which there are many of these friendly societies. They are in some respects a very good thing for the workingman, and can even provide for an old age pension.

In Auckland there are about 3,000 lodge members; many of these are married anc have childien; every child under the age of 18 comes on the physician's list. Take, for example, a man 31 years of age who joins the Manchester Unity of Odd Fellows; he pays $£ 310 \mathrm{~s}$. ( $\$ 17.50)$ per year; this covers all fees; 6 shillings (\$1.50) goes to the chemist. 14 shillings (\$3.50) goes to the doctor. The first fee of $£ 310 \mathrm{~s}$. $(\$ 17.50)$ also acts somewhat as an insurance to the member. If he is unable to follow his usual occupation, then he receives $\mathfrak{f l}(\$ 5)$ per week. If it is an accident, then he receives also from the employers' accirlent insurance. half his usual wages.

All the Auckland lodges united, and now have their own dispensary. They called for two medical officers, each to receive $£ 500(\$ 2.500)$ per year, and to divide the work; confinements, $£ 22 s .(\$ 10.50)$ and all venereals extra. But with the con tract I was asked to sign, and the work taking one's time early and la'e. I found a medical man was doing an injustice to himself. to his prtients and to the medical profession. The medical officer had but little time he could spend on each pa- tient. Some days my consultations and visits in a radius of $31 / 2$ miles would total such a number that they would average each as low as 9 pence ( 18 cents). I resigned, and the place was filled by a Chicago man.

There is another system of club practice which is very com. mendable. In one mining district the miners have a fund formed by deducting a weekly 9 pence (18 cents) from the wage. Then, in each case where a medical man is required, he is called and paid from the fund; it is unnecessary for me to say the medico is only called when he is really requirednot, as in the other form of club work, called for anything and everything.

There has been some effort among the members of the medical profession to combat the growth of lodge work; for exam. ple, to limit the membership to those receiving an income less than $£ 200(\$ 1,000)$ per year. This was unsuccessful. I found that $I$ was attending as a lodge member one of the members of the upper house of parliament, and many others with good incomes.

The consultation fees in general practice are 5 shillings $(\$ 1.25)$ in the country, $7 \mathrm{~s} .6 \mathrm{~d} .(\$ 1.871 / 2)$ in the city, $f 1 \mathrm{ls}$. $(\$ 5.25)$ in case of consultants.

P. M. Keller, M.D.

\section{Perforation in Typhoid.}

Owatonna, Misv., Aug. 9, 1904.

To the Editor:-The matter of perforation in typhoid enses has been discussed very extensively of late, both in society meetings, and in the medical journals. In your editorial of August 6 you have also referred to the symptoms. As the question of operation hinges on the diagnosis, of course for the time being that becomes the most important feature. There is one symptom that I have noticed to be invariably present, both in perforation from typhoid and from gastric ulcer, that I have never heard spoken of. During an experience extending over something over 33 years I have seen perhaps some six or eight of these cases, but have never seen a ease in which the pulse was not greatly accelerated-running from 160 up to such a rate that it was not susceptible of being counted. Another feature is that one may pour all of the stimulants and heart tonics into the patient that one pleases, and they produce no more effect than so much water. In most cases that I have seen the respiration has also been accelerated, but not in proporition to the pulse. The respiration is also superficial in character. I have also noticed quite a sudden drop in temperature.

Theo. L. Hater.

\section{Diagnosis of Scarlatina.}

Philadelphia, Aug. 8, 1904.

To the Editor:- I was very much interested in your issue of August 6, page 397, in re Schamberg's differential diagnosis between scarlet fever and "scarlatiniform erythema," of which teachers and text-books in my student days said nothing. Sev eral years ago I was called to see a young lady, about 17 years old, with sore throat, temperature about 100 , a somewhat rapid pulse, muscular soreness and a universal red eruption, which I declared to be scarlatinous. The mother and daughter both laughed and the former said: "Doctor, she has had this several times before, and Dr. $\longrightarrow$ and $\mathrm{Dr}$. - have pronounced it each time to be scarlet fever." There was later on some desquamation. My patient and I agreed to disagree, though she followed $\mathrm{my}$ directions as to treatment, and she recovered, but forgot to pay the bill.

E. W. Holmes.

\section{A Request to State Examining Boards-University of Michigan Has Two Departments of Medicine.}

AnN Arbor, Micr., Aug. 18, 1904.

To the Editor:-Please permit me through your columns to request the state merlical examining boards to distinguish in their reports of examinations between the Department of Medi. cine and Surgery of the University of Michigan and the Homeopathic Medical College of the University of Minhigan. These are two distinct schools, with different requirements for admission. and with essential differences in the courses offered.

Victor C. Vatghan. 